\title{
WOMEN AND MEDIA. INSTITUTIONAL CULTURES, INEQUALITY AND DYNAMICS OF POWER: 1982 TO $2002^{1}$
}

\author{
Sergio Ricardo Quiroga \\ sergioricardoquiroga@gmail.com \\ Instituto Cultural Argentino de Educación Superior (ICAES) - Argentina
}

Recibido: 06-02-2016

Aceptado: 14-05-2016

\section{Resumen}

Este trabajo estudia la participación de la mujer en los medios buscando examinar si existió discriminación hacia ellas, las características del empleo femenino, las culturas institucionales y las dinámicas de poder en el período comprendido entre 1982 y 2002 en la ciudad de Villa Mercedes, San Luis, Argentina. Esta elaboración es, además, un esfuerzo investigativo de intentar exhibir la situación de la mujer en el mundo de los medios en determinado contexto y momento histórico. La representación estereotipada de las trabajadoras femeninas en los medios de comunicación ha resultado uno de los temas centrales de las primeras revisiones y estudios sobre comunicación y género. Mediante el uso de herramientas de la metodología cualitativa usando el análisis documental y las entrevistas semiestructuradas examinamos las culturas institucionales y dinámicas de poder en las mujeres que trabajaron en los medios de comunicación en la ciudad de Villa Mercedes, San Luis.

Palabras Clave: Mujer, medios, empleo, participación.

\begin{abstract}
This paper studies the participation of women in the media seeking to examine whether there was discrimination against them, the characteristics of female employment, institutional cultures and the dynamics of power in the period between 1982 and 2002 in the city of Villa Mercedes, San Luis, Argentina. This development is also a research effort to try to display the status of women in the media world in a certain context and historical moment. Stereotypical representation of female workers in the media has been one of the central themes of the first reviews and studies on communication and gender. Using tools of qualitative methodology using document analysis and semi-structured interviews we examine the institutional and dynamic cultures of power in women who worked in the media in the city of Villa Mercedes, San Luis.
\end{abstract}

Keywords: Woman, media, employment, participation.

\footnotetext{
${ }^{1}$ Mujer y medios. Culturas Institucionales, desigualdades y dinámicas de poder: 1982 a 2002.
} 


\section{Introducción}

This paper studies the participation of women in the media trying to examine whether there was discrimination against them, employment characteristics, institutional cultures and the power dynamics in the period between 1982 and 2002 in the city of Villa Mercedes, San Luis, Argentina. Generally such investigations are rare and difficult to perform. This research is an important effort on the idea to display the status of women in the media world in particular historical moment, it was known as employment status, if gender inequalities exist, etc.

We look away from the now classic views of gender and liberal positions, for the idea that motivated this development, it is to expose as the woman has unfolded in the media, in a heyday of traditional media, organizations that have not always been friendly to the development of women's professional activity, in small regional contexts and work regulations and existing media at the time. The study is developed in the city of Villa Mercedes, in the province of San Luis, Argentina, a province generally middle-income per capita and sparsely populated. Villa Mercedes has in 1982 with about 55,000 inhabitants.

San Luis was a province where prevailing livestock and agriculture. The incipient industrialization of San Luis began around 1982, with the industrial promotion regime governing the country and had established that industries were established in the provinces of La Rioja, Catamarca, San Luis and San Juan were exempt from paying the income tax and value added tax. Law 22.021 was enacted only in 1979 and granted these benefits to the province of La Rioja. Then, between 1982 and 1983 the extent and duration of the tax regime for promotion Catamarca, San Luis and San Juan was sanctioned. Despite orders from the province of Mendoza in 2012, the Supreme Court of Justice of the Nation left sign a ruling that determined that companies based in La Rioja, Catamarca, San Luis and San Juan continue with tax benefits industrial promotion for two years, based on an extension provided by a national government decree.

Industrial promotion allowed the population of San Luis grows with the consequent increase in trade, industry and receipt of government taxes in the public area and the population grew progressively.

\subsection{The gender perspective}

Gender is a constitutive element of social relations and is a social construction that involves a set of agreements, but also a variable basis on which act the other generators dimensions of differences (ethnicity, age, educational level, social class, income, rural or urban status, etc.). Brönstrup Silvestrin (1999) states that in the first stage gender studies were used as a synonym for women to reverse a born political and social segregation that kept women out of 
history situation. The author claims that gender does not end there, your category is broader and addresses the difference of sexes, institutions, social structures, everyday practices, rituals and constitution of social practices (Magallon Portoles). The gender perspective presents women subjugated man so seeks to minimize the differences between the sexes, reducing the biological issue and affirming the cultural issue.

Gender is a category of analysis (Magallón Portoles, 1998) that humans organize their social activity and the social construction of the "three levels of recursive shaping" categories and powers of the genre involved: the symbolic, structural and individual (Sandra Harding, 1986-17-18). By not considering the natural reality, the concept of sex is neglected, presented as a social and culturally constructed concept, leading to gender, considered as a choice.

In a surprising trial, Hargreaves (1993) notes that not obvious, it is worth considering that men have had and have greater cultural power than women and it is not appropriate to minimize production and power struggle that liberal exhibit looks when emphasize that the increased activity of women occur in existing structures. In most activities, women are subordinate and no doubt, this situation besides being a creative challenge for her is clearly a disadvantage.

The task of locating the media-gender relationship in a broader as the culture and ideology theoretical grounds, is a powerful alternative when "the limitation of the theories that do not consider the construction of gender divisions as an element warns cultural analysis" (Hargreaves, 1993: 111). In this context, the author suggests, it is relevant to study female relationships as human activities, along with the ideas of freedom and human coercion, where a perspective to look at these processes in opposition is keeping the humanism of Marxism and the notion of culture as a system of meanings and values created by individuals and groups (Hargreaves 1993). Stereotypical representation of female workers in the media has been one of the central themes of the first reviews and studies on communication and gender. The media have been and are simultaneously players and creators of female and male models, through their speeches and performances realize what social and cultural in particular historical moment.

Several studies point out those women in the media continues to ignore and even increased the number of professional women in the communications sector, there are few that have come to occupy managerial positions in bodies that influence media policy communication (De los Rios and Martinez Almería, 1997).

This paper attempts to find traces of the dynamics of female jobs in the media, in the attempt to understand a reality reconstructed from a historical and present culture. It is unroll the skein of practices, social values or discrimination against women. We intend to find and visualize current and enduring social structures, in this case the employment and role of women in the media in a given society, to show us the historical crystallizations of meanings that are forgers of subjects and subjectivities. The presence of certain inequalities and discrimination refer us to the realization of women's inequality in the jobs hierarchy radio medium. 


\subsection{Previous studies}

Previous research is the study by Franquet Luzon and actions started in 2006 where the variable gender is examined from two perspectives: on the one hand, the presence and role of women journalists in digital newsrooms and on the other, women as actors of information that convey these means. Although, as the authors point out that in the context of globalization which is even more necessary to understand the dynamics of the different cultural industries, and specifically the media, linked to studies on women (Women's Studies) and of gender (gender Studies), research trends developed over decades in different american and european universities.

Highlights in the field of research the study by Franquet, Luzon and Ramajo (2006) in order to determine the role of women in the productive structure of the media, including studies of Tuchman Making News (1983); or research on the radio "Woman and Radio" of Karpf (1982); or "Unequal Opportunities. The case of women and the Media" of Gallagher (1983). Gallagher reports that one of the reasons of unequal opportunities for both exes in the field of communication is that these media at the time were dominated by men (Franquet, Luzon and Ramajo, 2006).

Franquet, Luzon and Ramajo (2006) also recognize research as "Women and media decision-making: the Invisible barriers", published by UNESCO in 1987, where the situation of women professionals is examined in five countries with completely different realities. The text presents the results of five case studies conducted within the program of Unesco on the Contribution of the Media to Promote Equality. One of the main concerns of UNESCO program has been to increase the access of women to positions of decision-making in the field of communication.

While there is a growing academic interest in the cultures of work (or cultures employment) in response to the growing demands of mid employment technologically inequality at work between men and women and increasing the precariousness of jobs this investigation examines the characteristics of participation of women in the media over a period of twenty years.

Denature certain re-created values that perpetuate gender discrimination is a critical challenge academy. Gender constructions are relevant in the study of the media because they transmit, create, reproduce and recreate stereotypes and cultural models, are analyzes that speak of social inequality that have historically been women, compared with men to access certain jobs in the world of work.

Through the career paths of women media we can examine perspectives on power relations, gender stereotypes that existed on the local radio. It is an invisible story about the participation of women in the media of Villa Mercedes San Luis, in this case, about the concrete practice of the exercise of the rights of women in the world of employment and employability in the media. 


\section{Women and Media}

We call participation of women in the media for his performance in the media as a journalist, broadcaster, host, programmer, directive, publicist or operator. That is, his professional work in so-called traditional media (newspapers, radio and television), since the proposed study is conducted at a historic moment in which other technologies exist in different social tasks. In this research the concept "women in the media" reaches all women who worked in the media, primarily as administrative, publicists, announcers, journalists and direction in different media or announcers.

The research taken as reference point 1982 because we consider it an important year in the history of Argentina and where sensitive the broken of military power after the Falklands War. It is a time in which the Argentina society lived the last months of so-called National Reorganization Process, launched in Argentina in March 1976 and was formed in a bloody military dictatorship that left thirty thousand missing and the loss of civil rights Argentine and freedom in various spheres of social life. In1982, LV 15 was the only radio in Villa Mercedes; the most important mass media with "El Diario de San Luis" but already appeared timidly radio frequency modulated called illegal radios, because the current law not contemplated in its articles.

On the other hand, is beginning to develop in the province an incipient process of industrialization in the province of San Luis based on the National Industrial Promotion Act complement the Act of Historical Reparation, it would take more force since 1982 and fully consolidate at 90, in this process, citizens of neighboring provinces, San Juan, Cordoba, Mendoza, Santa Fe and Entre Rios would be attracted by the possibility of achieving a permanent industrial employment in the city of Villa Mercedes and in different parts of San Luis . Many of them stayed to live in the city and in the province of San Luis, gradually increasing the population. This phenomenon was also favored by the limited industrial workforce of the city.

\subsection{Media in the 80s}

The participation of women in radio in the twenty years of this study can be characterized as a period of transformation of the Argentine radio universe with the emergence and growing presence of small FM radios in the period 1982-2002, which altered certain existing.

The end of the military dictatorship in Argentina accelerated since the Falklands War between Argentina and the United Kingdom of Great Britain which took place in the Falkland Islands, South Georgia and South Sandwich. The war took place from April 2, the day the Argentine landing on the islands, and June 14, 1982 with the surrender of the Argentine troops. 
Since the coup 1976, Argentina begins to accelerate de-industrialization and the negative impact of high external debt-in the standard of living of the population, which was rapidly diminishing their income, their access to health services, education and growth of basic social infrastructure and growth of its foreign debt. The policy linked to the rights of women during the 80 s was one of the central themes of political agenda during the administration of President Raúl Alfonsín (1983-1989).

The history of women in the media has tried to be rebuilt in a period in Argentina's history, which began at the end of the military dictatorship and the years of the so-called new democracy. For the purposes of analysis it has divided the period of investigation into two, seeking to deepen the performance of women in radio and its problems. The first period is marked by the end of the military dictatorship and the advent of FM radios, while the second period is marked by the deepening of democracy in Argentina, prevailing market ideology in different orders driven by policy liberal and new peronism as Carlos Menen and the lack of an adequate legal framework for the development of new radios.

\subsection{The radial regulatory environment living women in the media: period 1982-1992}

However, in the Military Dictatorship Argentina and many years of restoration of the democratic regime it remained in force the legal framework for broadcasting created by the Process of National Reorganization (1976-1983), and Argentine legislators had a debt to society on this issue. The situation was serious as Loretti warned when consciousness took some of the latest applicable laws on broadcasting came from governments de facto as sanctioned in 1957 (Decree Law 15,460 / 57, ratified by Law 14,467), in 1972 (19,798 telecommunications call, whose title $\mathrm{V}$ understood the rules on broadcasting) and in 1980, with 22,285, which was in force long (Loretti, 1995).

Law 22.285 was repudiated by a large number of scholars and women and men within the considered centralist, authoritarian and discriminatory. The Loretti himself warned that it was centralist because every application is focused on executive branch aside provinces, was authoritarian as its provisions limited the functioning of the media and information transmitted to the needs of national security and was discriminatory in as it excluded the right to be permitted to any legal entity other than a regularly constituted, ie excluded cooperatives commercial society, foundations and civil associations.

With the advent of democracy and the inauguration of President Raul Alfonsin, in the first months of 1984 the decree was issued from 1151 to 1184 postponing the implementation of the National Plan for Radio and public tenders were suspended until there is a new regulatory framework for Argentina's broadcasting. Loretti (1995) noted that disruption to the need for a new technical plan suitable to the needs of the country was justified in that decree. With this plan any Argentine citizen who intends to make use of any of the frequencies of our radio 
spectrum, but want to comply with all applicable laws and techniques that you might require, it has closed all legal possibility to exercise their right to communicate. However, alternatives radios or "clandestine radios" of frequency modulated came to occupy the Argentine airwaves causing the presence of a plurality of voices, different and alternative views, some democratization and new radio communication styles. By enacting Law 23.696 (article.65) the government sought a solution to the problem of clandestine radios and thought to open the doors to a new broadcasting law. Later, came the sanction of art. 65 of Law 23,696 and the Decree 1357 initiating a media record frequency modulated as highlighted by the argentine researcher.

\section{Methodology}

This inquiry is formulated using tools of qualitative methodology using document analysis and interviews to women who worked in the media in the city of Villa Mercedes, San Luis in the study period. The number of interviews was made twelve. The sample consisted of women aged 55 to 75 who acted in the media in the period under analysis. six workers were interviewed for the period 1982-1992 and six by the period 1992-2002.

The documentary analysis referred to the availability of media files investigated and the legal provisions concerning radio and media existed at that time in Argentina's history. To detect and find records and information in most cases it was disorganized, visited on several occasions to different media, spoke with directors and administrative and got to know the particular situation of each medium. In the period 1982-1992 the documentation was consulted key LV 15 Radio Villa Mercedes, Impulso Journal and La Voz del Sud Journal, while for the period 1992-2002 consultation held radios LV 15 Radio Villa Mercedes, FM FM Acuarelara, FM Sonix, Urbana FM, FM Tiempo, FM Independencia, Pasion FM and FM Latina, were almost $50 \%$ of the radio spectrum. FM stresses that both FM Acuarela, as FM Sonix were radio in the group that started in the 80 s and that were considered in this moment as "illegal".

\subsection{Interviews}

For the purpose of research, analysis split into two: 1982-1992 and 1992-2002. We formulate semi-structured interviews with women who acted in the media in both periods seeking a profile on respondents.

The interviews were conducted in the city of Villa Mercedes (SL) for the years 2013 and 2014. The profile of women was formed based on the following considerations a) women who had acted in the media during 1982 to 2002 b) they had aged between 55-75 years. For our 
survey found women who had acted as announcers, journalists, administrative and advertising section.

\subsection{Questions Inquiry}

We asked women who worked in the media during the years 1982 to 2002 :

1. How do you entered to work in the mass media??

2. Could have promotions in your work life? How was that process?

3. Do you remember what was the relationship in percentages between men was and women work in your midst at about that date? Options: a) 35\% $-65 \%$ in favor of men, b) $40 \%-60 \%$ c) $45 \% 55 \%$ in favor of men, d) $55 \%-45 \%$ in favor of women f) $50 \%-50 \%$.

4. Was there in the same job for men and women? How was your situation?

5. What charges in the middle considers that it was difficult to access for women?

6. Management and institutional culture medium promoting the employment of women?

7. In your mass media, remember if there were outstanding performances in women?

\section{Dictatorship Law: Time of the fledgling democracy. Period 1982-1992}

The women interviewed said they entered the middle by a call of the medium and in general not felt any discrimination or difference between them. The medium allowed them to develop a normal career for the parameters of the time. Not only women entered the radio medium without studies locution, so did the men. Both then should yield some oral examinations (tests locution), tests were recorded on the radio of the capital San Luis and then sent to the Federal Broadcasting Committee (COMFER) for evaluation. In Buenos Aires, young people studying speech at the Higher Institute of Radio Education (ISER). In the case of journalism, not being a career professional association, most journalists had no university degree.

Women who worked as announcers on radio and television said they had the same job since joining until graduated the medium. All workers consulted noted that almost failed to promotion in his career, more than the recognition of their seniority in the middle. That is, who entered as administrative, announcers and journalists continued that position until the end of their careers.

Women working in radio and television said that the relationship between men and women working was $40 \%-60 \%$ in favor of some men. The feeling was that there were more men working in the middle. In case, press the relationship women was $35 \%-65 \%$ in favor of men. 
The women interviewed stressed that there was generally the same job for men and women, although in the case of radio, the Head of Information Service was always man. In the case of advertising sections, the position was occupied by women and men in different media.

The club as a space for music selection, a work place was shared between men and women. The radio address was a virgin and unexplored for women in that period in the midfield. The field of advertising production was an area where female participation was protagonist. They concocted the jingles in the living creative LV 15 Radio Villa Mercedes located in Balcarce Street to 500, in the heart of the city.

The commercials and advertising were relevant in that defined as "commercial" radio, the time when the announcers made up about $60 \%$ of the employees of the station. The management was delegated to men called career in management, naming autocratically COMFER (Federal Broadcasting Committee).

At the time of the military dictatorship (1976-1983), were military or civilian who adhered to the regime, often inexperienced in the world of communication and radio in particular. The privatization of LV 15 Radio Villa Mercedes in December 1983 coincided with the birth of some alternative radio Frequency Modulation (FM), which appeared in crisis with the restrictive regulatory scheme, existed. The woman is better developed in the radial world advertising areas, music production, the tasks of speech and journalism, but not in the field of management of the stations, adverse to them, partly explained by discrimination, values and prevailing gender inequality in society.

"A lifetime of work, the best efforts, few faults, but in the end the climb was difficult and hierarchies remained" said Norma, working the period 1992-2002. Story exposing the difficulties climb positions and functions of women workers.

Women who worked in the administration and publicity in the media said they had the same job and fulfilling activity than men. Both groups felt that the activities related to the cameras, recording and radio operation were carried out by men and that the directorship of the medium was almost always occupied by men. In the case of the press, no woman became director of the medium. The institutional culture - as expressed women interviewed - not visibly promoting the employment of women in the middle.

There were no substantial changes in the female performance in the early development of so-called illegal radios - means "illegal" by the "legal" radios - these alternative means easily arose from the initiative of individuals and did not have any regulation in the law of the dictatorship military.

The prominent newscaster Titi Otazu stressed that "the participation of women in radio as an announcer from the 70s until today was always outstanding" stating that women as radial working as a broadcaster and journalist was relevant. 
Table 1. Table of Concepts 1982-1992

\begin{tabular}{|c|c|}
\hline Concepts & Development \\
\hline $\begin{array}{l}\text { How do you entered to } \\
\text { mass media? }\end{array}$ & $\begin{array}{l}\text { Most of the women interviewed reported that entry to the media } \\
\text { by a call from the institution itself. They emphasize that received } \\
\text { no discrimination in their working function. The charges were } \\
\text { objects of competition in the media were administrative, } \\
\text { publicists, journalists and announcers }\end{array}$ \\
\hline $\begin{array}{l}\text { Did you climb in your } \\
\text { work life? How was this } \\
\text { process? }\end{array}$ & $\begin{array}{l}\text { All workers consulted noted that almost failed to promotion in his } \\
\text { career, more than the recognition of their seniority in the middle. } \\
\text { That is, who entered as administrative, announcers and journalists } \\
\text { continued that position until the end of their careers. }\end{array}$ \\
\hline $\begin{array}{l}\text { Do you remember the } \\
\text { relationship in percentages } \\
\text { between men and women } \\
\text { workers? }\end{array}$ & $\begin{array}{l}\text { Women working in radio and television said that the relationship } \\
\text { between men and women working was } 40 \%-60 \% \text { in favour of } \\
\text { men at about this period. } \\
\text { Some of them stand out was that there was a feeling that there } \\
\text { were more men working in the middle, but not specifically may } \\
\text { require. In case, press the relationship women was } 35 \%-65 \% \text { in } \\
\text { favour of men. }\end{array}$ \\
\hline $\begin{array}{l}\text { Was there in the same job } \\
\text { for men and women? } \\
\text { How was your situation? }\end{array}$ & $\begin{array}{l}\text { The women interviewed stressed that there was generally the } \\
\text { same job for men and women, although in the case of radio, the } \\
\text { Head of Information Service was always man. In the case of } \\
\text { advertising sections, the position was occupied by women and } \\
\text { men in different media. In the case of print media, women } \\
\text { performed tasks journalist and publicist. }\end{array}$ \\
\hline $\begin{array}{l}\text { What jobs or functions in } \\
\text { the media considered that it } \\
\text { was difficult to access for } \\
\text { women? }\end{array}$ & $\begin{array}{l}\text { In the radio, a charge of difficult access was the Head of the } \\
\text { Information Service or director of the media. Journalistic } \\
\text { functions were performed by men and women like advertising } \\
\text { work. In the case of the press, the directors were always men. The } \\
\text { woman stood in the advertising and administrative tasks }\end{array}$ \\
\hline $\begin{array}{l}\text { Does the management and } \\
\text { institutional culture of } \\
\text { mass media promoting the } \\
\text { employment of women? }\end{array}$ & $\begin{array}{l}\text { There was no political or institutional management to promote a } \\
\text { culture of greater participation of women in the labor scenario. } \\
\text { Women workers felt that there was a tacit discrimination but that } \\
\text { it responded to the prevailing social values. }\end{array}$ \\
\hline $\begin{array}{l}\text { In your workplace, } \\
\text { remember if there were } \\
\text { outstanding performances } \\
\text { in women? }\end{array}$ & $\begin{array}{l}\text { Yes, there were prominent women workers interviewed } \\
\text { commented. For example, announcers as Norma Trujillo, who } \\
\text { was a complete professional but never, turned the radio news } \\
\text { service. }\end{array}$ \\
\hline
\end{tabular}

Table prepared by the author of the article based on the information collected 


\subsection{Law and Democracy Dictatorship. Period 1992-2002}

In 2002, was continued deepening a process of frequency allocation of FM radios, despite the existence of multiple projects on state regulation of radio services existing ongoing for many years as a legacy of the military dictatorship (the new law would arise in Argentina, until October 2009).

Faced with a radio map in 2002 it made up almost 30 FM (called illegal or clandestine radios because they were outside the law) and only an AM radio (LV 15 Radio Villa Mercedes, San Luis) found few stations that had a web page to place or platform news and as a means of communication with their audiences.

The size and depth of the Argentina crisis is felt in different spheres of life and the media are not insulated from its effects. It is therefore not easy for us to determine how many FM radios actually existed at a time when the city of Villa Mercedes by the dispersion of the dial and the absence of a legal framework.

Table 2. Table of Concepts 1992-2002

\begin{tabular}{|c|l|}
\hline Concepts & \multicolumn{1}{c|}{ Development } \\
\hline $\begin{array}{c}\text { How do you entered to } \\
\text { mass media? }\end{array}$ & $\begin{array}{l}\text { Most of the women interviewed reported that entry to the media } \\
\text { by a call from the institution itself. They emphasize that received } \\
\text { no discrimination in their working function. }\end{array}$ \\
\hline $\begin{array}{c}\text { Did you climb in your } \\
\text { work life? How was this } \\
\text { process? }\end{array}$ & $\begin{array}{l}\text { The interviewees responded that generally failed to promotion in } \\
\text { his professional career but that did not exist in his opinion the } \\
\text { idea of discrimination or visible discrimination. }\end{array}$ \\
$\begin{array}{c}\text { Do you remember the } \\
\text { relationship in percentages } \\
\text { between men and women } \\
\text { workers? }\end{array}$ & $\begin{array}{l}\text { Women who worked in the media stated that the relationship } \\
\text { between men and women was } 45 \% \text {-55\% in favor of men. } \\
\text { advertising administrative tasks showed that over time had the } \\
\text { same job, without major changes. Both groups felt that the } \\
\text { activities related to the cameras, recording and radio operation } \\
\text { were carried out by men and that the directorship of the medium } \\
\text { was almost always occupied by men. }\end{array}$ \\
\hline $\begin{array}{c}\text { Was there in the same job } \\
\text { for men and women? How } \\
\text { was your situation? }\end{array}$ & $\begin{array}{l}\text { The women interviewed said that men and women in the media } \\
\text { could perform the same job functions, but not generally senior } \\
\text { functions. cases of women holding leadership positions in some } \\
\text { radios and a newspaper occasionally }\end{array}$ \\
\hline $\begin{array}{c}\text { What jobs or functions in } \\
\text { the media considered that it } \\
\text { was difficult to access for } \\
\text { women? }\end{array}$ & $\begin{array}{l}\text { The women interviewed stressed that in the advertising section of } \\
\text { some stations, advertising management at times was directed by } \\
\text { women, not the direction of the medium was always conducted } \\
\text { by men. }\end{array}$ \\
\hline
\end{tabular}




\begin{tabular}{|c|l|}
\hline $\begin{array}{c}\text { Does the management and } \\
\text { institutional culture of mass } \\
\text { media promoting the } \\
\text { employment of women? }\end{array}$ & $\begin{array}{l}\text { Generally means there was no political or institutional } \\
\text { management to promote a culture of greater participation of } \\
\text { women in the labor scenario. Women workers felt that the was } \\
\text { a tacit discrimination, but that it could respond to certain } \\
\text { prevailing social values that hinder equality of women in all } \\
\text { social and work settings. In this period, there was greater } \\
\text { recognition to women's participation in the media. }\end{array}$ \\
\hline $\begin{array}{c}\text { In your workplace, } \\
\text { remember if there were } \\
\text { outstanding performances } \\
\text { in women? }\end{array}$ & $\begin{array}{l}\text { In the radio and television announcers involving large as Titi } \\
\text { Otazu and Norma Trujillo stands. There were no major references } \\
\text { of this concept in the written press. }\end{array}$ \\
\hline
\end{tabular}

Table prepared by the author of the article based on the information collected

The women interviewed said they entered the middle by a notice of competition and generally did not feel any discrimination or difference in favor of the employee man.

Women who worked in the media stated that the relationship between men and women was $45 \%-55 \%$ in favor of men. Women who worked as announcers on radio and television said that over time had the same job, without major changes. Women who worked in the administration and publicity in the media expressed continued same job for his career. Both groups felt that the activities related to the cameras, recording and radio operation were carried out by men and that the directorship of the medium was almost always occupied by men. Women surveyed said that institutional culture medium, the dynamics of labor mobility, not promoted, or left to promote the employment of women. Preeminence in the elections of men for driving charges was made of "natural" way. During the development of "illegal" means frequency-modulated -radios the law of the military dictatorship did not complete, women about the risk itself and dynamism of media performance yet fulfilled the roles of traditional media.

\section{Employment and Institutional Cultures}

As for the characteristics of employment, institutional cultures and power dynamics present in the periods examined may note that:

\subsection{Employment characteristics}

As for the nominal characteristics of female employment in the period examined were the duties and functions that the media adopted at the time as administrative employees, employees 
of advertising, announcers, editors and journalists. No employability characteristics attributed to sex or gender were observed, although it is noteworthy that in the radio media there was a tendency to form media proposals where participants tended to complement each other, generally being a man and a woman newscaster or reporter. The selection parameters of jobs in the print media consisted of general examinations writing and news writing. In some media were relevant characteristics of voice, intonation and clarity and in television and good speech "television presence" of subjects. For administrative or advertising sales charges, usually women were selected because they were considered more apt than men to these tasks.

\subsection{Institutional cultures}

Since the contributions of the interpretative-symbolic paradigm conceives reality as signified by each of the people. Reality shows as a set of meanings that a group of people assigned to each of the facts or events, which generates customs, rituals, values, ceremonies which form the organizational identity.

As for institutional cultures established by the media in view of the workers, we understand according to the voices of imaginary built by workers means that although there were values and prevailing discourses in society that did not recognize social equality in general and in particular labor equality of women's work, we recognize that in the world of the media, women competed or worked on almost equal terms with men. We also highlight that organizations thrive in staff selection processes to hire people who fit with them, accepting their values, norms and customs (Ritter, 2008).

The institutional culture is understood as those forms that are members of the group or organization based on a set of shared beliefs and values. In terms of Ritter (2008) culture provides a common framework that allows a more homogeneous conception of reality and therefore a similar pattern of behavior for members of the organization. In the case of the media LV 15 Radio Villa Mercedes (S.L.) was recognized identification and pride of working for belonging to a relevant radio in the city.

\subsection{Power dynamics}

Institutional cultures present in force by the dynamics of power in that period show strong leadership role of management in the period 1982-1992, uniqueness and high structuring charges in the media given during that period.

Knowing the power dynamics allows us to recognize the relationship manager-employee in the media object of this analysis, prepared by the carriers of powers, builders visible practices of resistance against institutional power, but expressed in terms of the processes of reproduction of social structures. 


\section{Conclusions}

The information gathered from interviews would note that the participation of women in the media in the period 1982-2002 was prima facie as there were certain areas of work in the media that could not cross, for the social value of managers in under prevailing social and cultural trends in society.

The exhibition showed the difficulties workers climb positions and functions with which the workers began. If they could keep their jobs well, the rise was complicated. The information provided by the interviewed women realizes that women's access to management functions virtually absent. The low visibility of women in management positions is also due to the relations of power-women and men in public spaces and in social organizations and in education, in the media, in political participation, the period under review. We haven't confirmed that the arrival of women to charges of driving means as often as men, although warned slow growth in the field of the different management and leadership roles in the analysis period.

In the interviews with recognized radio referents in the investigations carried out in a group made up of traditional and alternative media means, it appears that women in the period beginning in the years 1982-2002 could reach some tasks in the media local communication and that such participation was, although they had no professional qualifications.

While it is remarkable professional growth of women, there were certain areas of the communications field that could not pass through, by the existence of prevailing sensitive social and cultural trends in society - the idea of cultural arbitrary - they are indicating that access women to these functions will have to overcome resistance still strong and invisible. Inequalities and discrimination that refer to women's invisibility in the jobs hierarchy radio medium. Current and enduring social constructions in a given society, historical crystallizations senses, forger of subjects and subjectivities.

The participation of women in radio has been growing and can say that is increasingly places or spaces to develop professionally in the media world since its early involvement in the reporting period. However, I failed to reach charges of driving radio as assiduously as men, although its growth was noticed in the field of the different management and leadership roles in the analysis period.

The growth of women in the various activities of the media has difficultly given the current prevailing culture and persistent gender inequalities in the examined historical time, values that still govern our societies. The participation of women has become strong and sensitive changes in a growing consideration of gender. However, although their presence in the middle in the time before us, has increased, there were areas or tasks of the unexplored means to them. Despite the gradual improvement in the participation of women in radio, there are some limitations as to the role they must meet in the middle. It is precisely the place of 
hierarchy on the radio or the media, which is the most difficult to reach for them and in which the ideologies and social visions, male cultural patterns historically constructed, which still remain stable and in tension and are changing progressively with increasing importance, transformation and breadth that society and the media give to these issues.

The low visibility of women in such positions is also due to the relations of power-women and men in public spaces, such as in education, in the media, in political participation. Charges teacher in primary education Argentina have been traditionally occupied by women. However, traditionally power relations were penetrated by elements such as machismo, violence and power, among others, they have placed women only with "roles of secondary productive work" and not hierarchical levels of decisions. Male domination in the media and female subordination appears so natural, clear and legitimate; exposing a gender categorization affects the whole society in general and to the presence of women on the radio, in particular.

The gender category for understanding the conditions that allow the preeminence and domination of men over women in local radio, appear natural and unquestioned. This feature of invisibility is evident in the local radio (1982-2002) and sociability workplace where "innocent" naturalized unequal, discriminatory and chauvinistic male, in synergy with traditional gender stereotypes are perpetuated cultural ideologies. The secondary roles in the workplace were made primarily for women. This explains the absence and invisibility of the charges in the radial direction and journalism against men in local radio during the years 1982-2002.

We can estimate that the participation of women in journalism has grown substantially despite forms of work that were observed in the media, indicated that subsisted preeminence in traditional media (newspapers, radio, television, etc.) of the working man. The woman in the communication field, in this small regional contexts progressed progressively in a labor camp in a context of some media anarchy, professional cultures discriminatory, and lack of democratic civic culture in which inequalities of argentine society.

\section{BIBLIOGRAPHY}

- Abril, Natividad (1994): La participación de las mujeres en los medios de comunicación de Euskadi y en la publicidad. Vitoria-Gasteiz, Emakunde Instituto Vasco de la Mujer.

- Adler, Nancy (1988): "Women: world class managers for global competition". In: Academy of Management Executive, vol. 2, no. 1, febrero, pp. 11-19.

- Andréu, Jaime; García Nieto, Antonio y Pérez, Ana María (2007): “Evolución de la teoría fundamentada como técnica de análisis cualitativo". In: Cuadernos Metodológicos del CIS, $\mathrm{n}^{\circ}$. 40, pp. 1-205.

- Antequera Yepes, Mónica (2005): El papel de la mujer en la dirección y gestión de las empresas informativas en España a principio del siglo XXI: un análisis prospectivo. Tesis Doctoral (inédita). Universidad Complutense de Madrid. 
- Brönstrup Silvestrin, Celsi (1999): "Gênero nos meios e comunicação". In: Revista Brasileira de Ciencias da Comunicacao (INTERCOM), XXII (1), pp. 163-167.

- De Barbieri, Teresita (1993): "Sobre la categoría género. Una introducción teóricometodológica". In: Debates en Sociologías, no .18 . Lima: Pontificia Universidad Católica del Perú-Departamento de Ciencias Sociales.

- De los Ríos, José y Martínez Almería Joaquina (1997): "La mujer en los medios de comunicación”. In: Revista Comunicar, nº. 9, pp. 97-104.

- Franquet, Rosa; Luzón, Virginia y Ramajo, Nati (2006): "Mujer y medios de comunicación on-line. Un análisis de género". In: Fernando Sabés (ed.): Análisis y propuestas en torno al periodismo digital. Huesca: Ayuntamiento de Huesca / Asociación de la Prensa de Aragón.

- Gallego, Johana; Altes, Elvira; Melus, María, Eugenia; Soriano, Jaume y Canton, María José (2002): "La prensa diaria por dentro: mecanismos de transmisión de estereotipos de género en la prensa de información general". In: Anàlisi: quaderns de comunicació i cultura, no ${ }^{\circ}$ 28, pp. 225-242, 227.

- García-Leiva, Patricia (2006): Estereotipos de género en publicidad televisiva. Madrid: PROQUEST Information and Learning.

- Hall, Stuart (1997): “Introduction". In Stuart Hall (ed.): Representation: Cultural representations and signifying practices. London: Sage, pp. 1-11.

- Harding, Sandra (1986): The science question in Feminism. Ithaca: Cornell University.

- Hargreaves, Jennifer (1993): "Promesas y Problemas en el Ocio y los Deportes Femeninos". In: Materiales de Sociología del Deporte. Madrid: Ediciones de la Piqueta, pp. 109-132.

- Loreti, Damián (1995). El derecho a la información. Buenos Aires: Paidós.

- Magallón Portoles, Carmen (1998) (ed.): Pioneras Españolas en la Ciencia. Las Mujeres del Instituto Nacional de Física y Química. Madrid: Consejo Superior de Investigaciones Científicas.

- Ritter, Michael (2008): Cultura Organizacional. $1^{\circ}$ edition. Buenos Aires: La Crujía.

- Rovetto, Florencia (2013): "Estudios feministas y medios de comunicación: Avances teóricos y periodísticos en España y Argentina”. In: Foro Científico Facultad de Ciencias Sociales, $\mathrm{n}^{\mathrm{o}}$. 16, Universidad de Playa Ancha Valparaíso, Chile, [on line] Available at http://www.revistafaro.cl [02/03/2015].

- Soriano, Jaume (2005): “La incorporación de la mujer a la profesión periodística en España: crítica a la hipótesis de la feminización” In:. F@ro, no. 2, pp. 353-368.

- Steeves, H. Leslie (1987): "Feminist theories and media studies". In: Critical Studies in Mass Studies, vol. 4, no. 2, pp. 95-135.

- Tuchman, Gaye (1978): Making News. Nueva York: The Free Press.

- UNESCO (1987): Women and media decision-making: The invisible barriers. Paris: UNESCO.

- Van Zoonen, Liesbet (1994): Feminist media studies. London: Sage.

- Wilkins, Karin Gwinn (1999): "Development discourse on gender and communication in strategies for social change". In Journal of Communication, vol. 49, nº 1, pp. 46-68. 